\title{
Survey
}

\section{Prescription Drugs and the US Workforce: Results from a National Safety Council Survey}

\author{
Alaa Abd-Elsayed, MD, Mathew Fischer, MD, Jonathan Dimbert, MS, \\ and Kenneth James Fiala, BS
}

From: Anesthesiology, University of Wisconsin School of Medicine and Public Health, Madison,

Wisconsin, USA

Address Correspondence: Alaa Abd-Elsayed, MD, MPH Medical Director UW Pain Services Medical Director, UW Pain Clinic

Section Head, Chronic Pain

Medicine, Anesthesiology University of Wisconsin School of Medicine and Public Health, Department of Anesthesiology 600 Highland Avenue, B6/319 CSC Madison, WI 53792-3272 E-mail: alaaawny@hotmail.com

Disclaimer: There was no external funding in the preparation of this manuscript. Conflict of interest: Authors have no conflict of interest related to this work. Dr. Abd-Elsayed is a consultant for Medtronic, StimWave and Avanos.

Manuscript received: o6-16-2019

Revised manuscript received: 07-31-2019

Accepted for publication: 08-05-2019

Free full manuscript: www.painphysicianjournal.com
Background: The cost of chronic pain in the United States is extremely high. Opioids are one of the most common medications prescribed for the treatment of chronic pain, and their misuse and addiction have been of concern. It has been found that opioids are frequently abused and negatively impact the American workforce.

Objectives: The objective of this study was to obtain data on US employers' concerns and priorities, perceptions of prescription drug abuse, perceived impact of prescription drug use on the workplace, identification of and response to drug abuse, perceived ability to handle prescription drug abuse in the workplace, and workplace initiatives, employee assistance programs, employee drug testing, workplace prescription drug training, insurance coverage of alternative treatment, and overall preparedness to deal with the issue.

Study Design: This research used an employer proprietary questionnaire created by members of the National Safety Council in cooperation with market research experts at B2B International.

Setting: Employers surveyed via an online survey represent diverse industries and geographical areas.

Methods: The research was conducted using a proprietary questionnaire. Participants were recruited from a sample of verified panelists through Research Now, and fieldwork was conducted online by B2B International. This report is on 501 interviews that each represent a US employer with 50 or more employees. The employers sampled are extremely diverse in not only size and industry, but also geography and centralization.

Results: Our results showed that $67 \%$ of employers reported concerns related to prescription drug misuse, which was comparable to workplace violence and more concerning than the use of illegal drugs. Sixty-one percent reported concerns related to prescription opioids, which was a higher concern than using anti-anxiety medications, stimulants, and even heroin.

Limitations: Survey study with descriptive analysis with limited sample.

Conclusions: Prescription drug misuse and abuse concern American employers. Their side effects are clear, but employers are less likely to acknowledge their detrimental business effect. Employers report being unprepared for dealing with issues related to this; however, the firms with programs in place feel more prepared to deal with misuse and abuse.

Key words: Prescription drugs, US workforce, chronic pain

Pain Physician 2020: 23:1-16 hronic pain is pervasive among Americans, affecting nearly 100 million adults and causing an estimated $\$ 635$ billion in annual medical costs and lost productivity (1). As such, prescription pain medications have been grounds for significant distress among both public health and clinical communities. Much of this concern is related to opioid analgesics, due to their ubiquity as well as 
their potential for misuse and addiction. Opioids are widespread, with 259 million prescriptions written in 2012 (2). Up to $20 \%$ of patients seen in the ambulatory care setting for pain in 2010 were treated with an opioid analgesic (3). While potential adverse reactions to opioids are many, most concerning are the possibilities of addiction, misuse, and even death. In 2015, an estimated 2 million Americans abused prescription opioid analgesics, accounting for $10 \%$ of all Americans with a substance use disorder (4). In addition to their public health impact, opioid analgesics are demonstrated to have a sizeable negative effect on the productivity of America's workforce. Those diagnosed with opioid abuse disorder incur over $\$ 14,000$ in marginal annual health care costs compared to nonabusers (5). Including expenditures related to health care, treatment of addiction, lost productivity, and involvement of the criminal justice system, the estimated economic burden of opioid analgesic misuse reaches $\$ 78.5$ billion annually (6). These factors, among others, have led policymakers and public health organizations to declare a crisis surrounding opioid use in America.

This paper presents results from a National Safety Council (NSC) survey that queried US employers' perceptions of and experiences with prescription drugs in the workforce (7).

\section{Methods}

This research was completed using a proprietary questionnaire developed by members of the NSC in cooperation with market research experts at B2B International. Participants were recruited from a sample of verified panelists through Research Now, and fieldwork was conducted online by B2B International between December 12 and 29, 2016. Overall responses throughout this report have a $4.4 \%$ margin of error at the industry-standard $95 \%$ confidence level.

This report builds on 501 interviews with Human Resources (HR) decision-makers across a geographically representative sample of US employers with 50 or more employees. All respondents are HR decision-makers who are involved in, or ultimately responsible for, decisions about their workplace's strategy and policies with regards to health and safety, health care benefits, employee policy and/or drug and alcohol policy. The majority of respondents work specifically in HR; however, other roles include senior management, employee benefits specialists, and others. Seventeen percent of respondents are NSC members.
The firms sampled are diverse across geography, size, industry, and centralization (Fig. 1). All comprise 50 or more employees, and nearly two-fifths have over 1,000 employees. While $23 \%$ of the businesses are global, all firms are based in the United States and all responses are focused on US operations. Over $85 \%$ of respondents have at least some employees in jobs that require handling of machinery, tools and/or vehicles, and approximately half of respondents have at least some of their workforce covered by union regulations or contracts.

\section{Results}

Survey responses are analyzed across several domains, including employer concerns and priorities, employer perceptions of prescription drug abuse, impact of prescription drug misuse/abuse on the workplace, identification of and response to drug abuse, ability to handle prescription drug abuse in the workplace, common responses to substance abuse, policy coverage, workplace addiction initiatives, insurance coverage of alternative treatment, and overall preparedness to deal with the issue.

\section{Employer concerns and priorities}

Respondents were asked to assign a level of concern to the impact of various issues on their organization, with possible responses including "major concern," "minor concern," "not a concern," or "I don't know." While US employers are most concerned about benefit costs and hiring people with the right skills, prescription drug abuse and illegal use or sale of drugs are each considered a major concern by $23 \%$ of respondents (Fig. 2). Sixty-seven percent of respondents report that prescription drug misuse among their employees is either a major concern or minor concern. Prescription drug misuse is significantly less concerning among professional services firms than other industries, with just over half of employers saying that it is a concern (Table 1). By comparison, industrial firms are significantly more concerned about the issue, with $76 \%$ reporting prescription drug misuse as a concern for their firm.

Further stratification reveals that 6 in 10 employers are concerned about the negative impact of opioids, specifically, on their workforce, with approximately one in 4 finding opioid analgesics a major concern (Fig. 3). Industrial organizations are significantly more concerned about opioid analgesics, while professional services firms are less so; larger firms also tend to be more concerned than their smaller counterparts (Table 2).

Concern is significantly higher among those who have experienced a prescription drug-related 

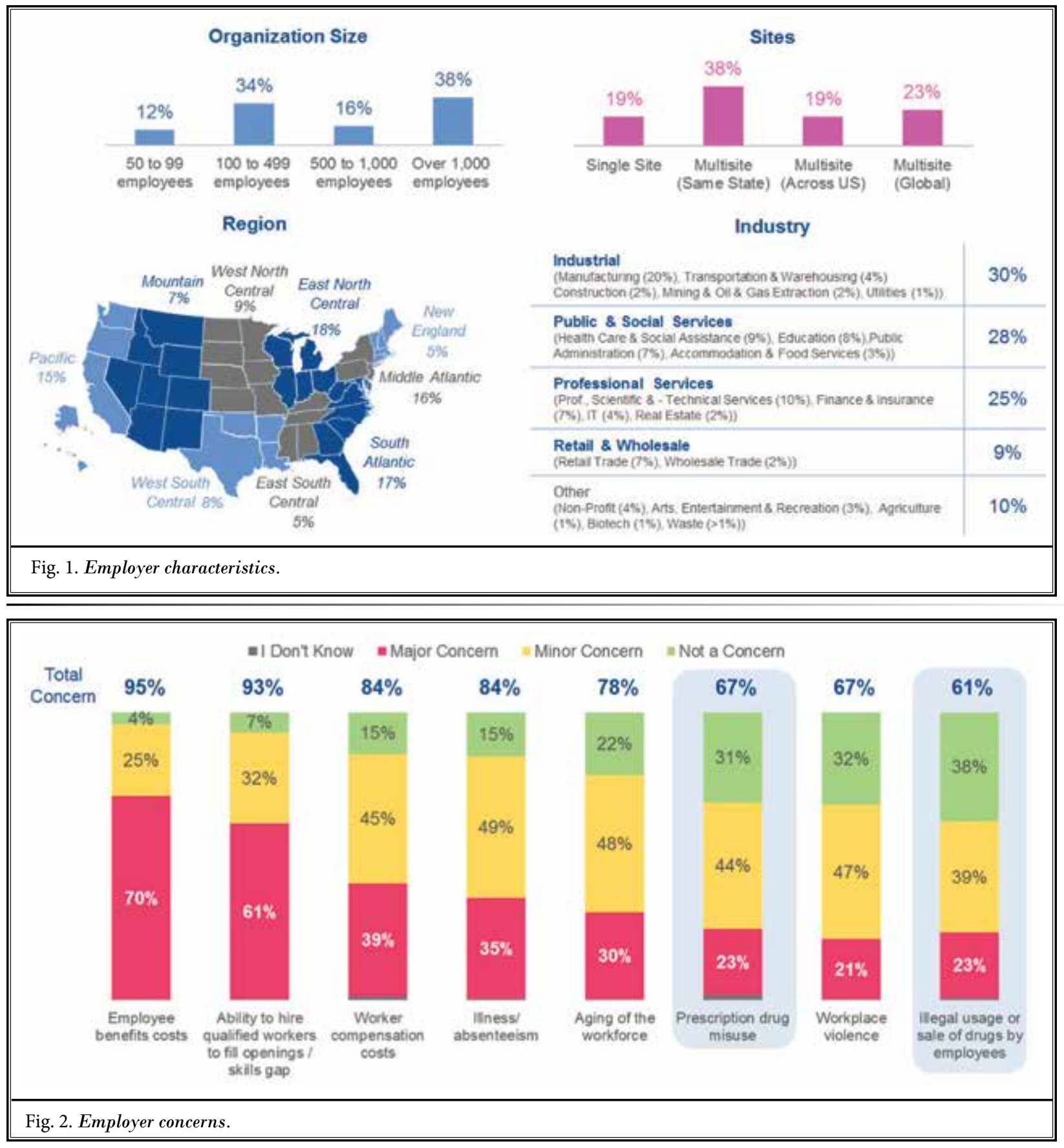

incident at work, depending on the incident (e.g., usage, overdose, complaints); it is also higher among employers who conduct drug testing (Table 2).

\section{Employer perceptions of prescription drug abuse}

On a 5-point Likert scale from "strongly agree" to "strongly disagree," employers were asked to rate their concordance with several statements about the misuse and abuse ("misuse/abuse") of prescription drugs.

Overall, $80 \%$ of respondents agree that misuse/ abuse of prescription drugs is a sign of addiction, and a majority believes that misuse/abuse of prescription drugs is a bigger problem for Americans than abuse 
Table 1. Employer concerns by industry type.

\begin{tabular}{|c|c|c|c|c|c|}
\hline & \multirow{2}{*}{ \% Concem } & \multicolumn{4}{|c|}{ Industry Type } \\
\hline & & Industrial & $\begin{array}{c}\text { Public \& Social } \\
\text { Services }\end{array}$ & $\begin{array}{l}\text { Professional } \\
\text { Services }\end{array}$ & $\begin{array}{c}\text { Retail \& } \\
\text { Wholesale }\end{array}$ \\
\hline Base & 501 & 148 & 138 & 120 & 47 \\
\hline Employee benefits costs & $95 \%$ & $98 \%$ & $91 \%$ & $97 \%$ & $96 \%$ \\
\hline Ability to hire qualified workers to fill openings / skills gap & $93 \%$ & $96 \%$ & $92 \%$ & $93 \%$ & $89 \%$ \\
\hline Worker compensation costs & $84 \%$ & $90 \%$ & $88 \%$ & $73 \%$ & $81 \%$ \\
\hline Illiness/absenteeism & $84 \%$ & $89 \%$ & $86 \%$ & $78 \%$ & $79 \%$ \\
\hline Aging of the workforte & $78 \%$ & $88 \%$ & $75 \%$ & $71 \%$ & $72 \%$ \\
\hline Prescription drug misuse & $67 \%$ & $76 \%$ & $67 \%$ & $53 \%$ & $70 \%$ \\
\hline Workplace violence & $67 \%$ & $74 \%$ & $68 \%$ & $53 \%$ & $72 \%$ \\
\hline |legal usage or sale of drugs by employees & $61 \%$ & $72 \%$ & $59 \%$ & $48 \%$ & $68 \%$ \\
\hline
\end{tabular}

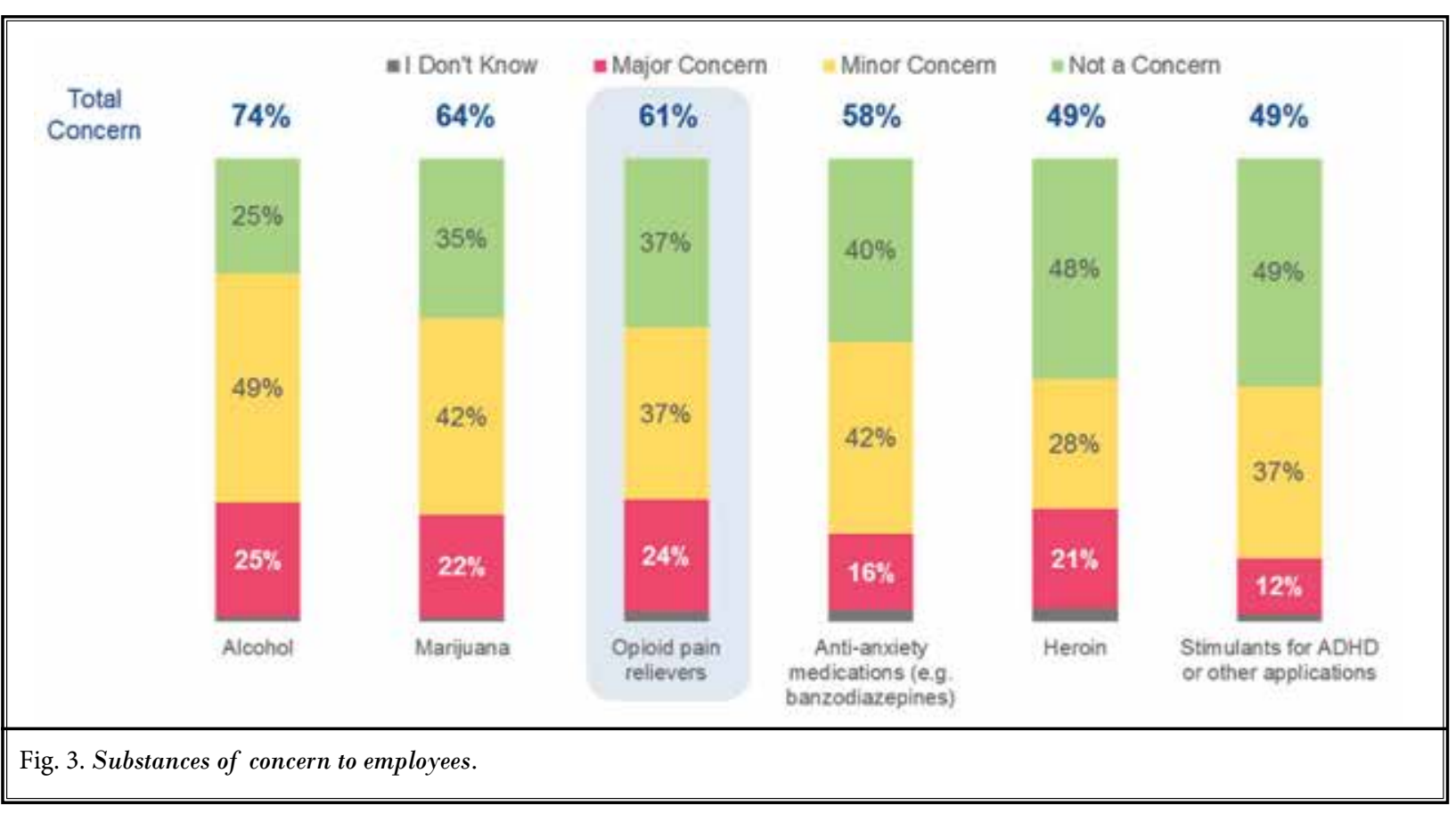

of illegal drugs (Fig. 4). Around a quarter of employers mention misuse/abuse of prescription drugs being a problem in their workforce (Fig. 5). Across the board, attributes relating to the business impact of the issue are less recognized than those relating to the health and social impacts of prescription drug misuse/abuse.
Employers who agree that misuse/abuse of prescription drugs is a justifiable reason to fire an employee are very likely to act on that belief, with over 9 in 10 likely to dismiss that employee; in contrast, those who recognize it as an issue in their workforce or recognize its impact on employee retention are 
Table 2. Substances of concern to employers by industry type and organization size.

\begin{tabular}{|c|c|c|c|c|c|c|c|}
\hline & \multirow[b]{2}{*}{ Whi Concern } & \multicolumn{4}{|c|}{ Industry Type } & \multicolumn{2}{|c|}{ Organization Sze } \\
\hline & & Industrial & $\begin{array}{l}\text { Public \& } \\
\text { Social } \\
\text { Services }\end{array}$ & $\begin{array}{l}\text { Professional } \\
\text { Services }\end{array}$ & $\begin{array}{l}\text { Retall } 8 \\
\text { Wholesale }\end{array}$ & $\begin{array}{l}1,000 \\
\text { employees or } \\
\text { less }\end{array}$ & $\begin{array}{l}\text { Over } 1,000 \\
\text { employees }\end{array}$ \\
\hline Base & 501 & 148 & 138 & 120 & 47 & 309 & 192 \\
\hline Alcohol & $74 \%$ & $82 \%$ & $72 \%$ & $66 \%$ & $72 \%$ & $72 \%$ & $77 \%$ \\
\hline Marijuana & $64 \%$ & $78 \%$ & $57 \%$ & $49 \%$ & $77 \%$ & $62 \%$ & $68 \%$ \\
\hline Opioid pain relievers & $61 \%$ & $73 \%$ & $59 \%$ & $48 \%$ & $66 \%$ & $57 \%$ & $68 \%$ \\
\hline $\begin{array}{l}\text { Anti-anxiety medications } \\
\text { (benzodiazepinesor other sedatives) }\end{array}$ & $58 \%$ & $64 \%$ & $60 \%$ & $47 \%$ & $53 \%$ & $53 \%$ & $65 \%$ \\
\hline Stimulants for ADHD or other applications & $49 \%$ & $53 \%$ & $54 \%$ & $38 \%$ & $49 \%$ & $45 \%$ & $56 \%$ \\
\hline Heroin & $49 \%$ & $58 \%$ & $49 \%$ & $33 \%$ & $55 \%$ & $45 \%$ & $56 \%$ \\
\hline
\end{tabular}

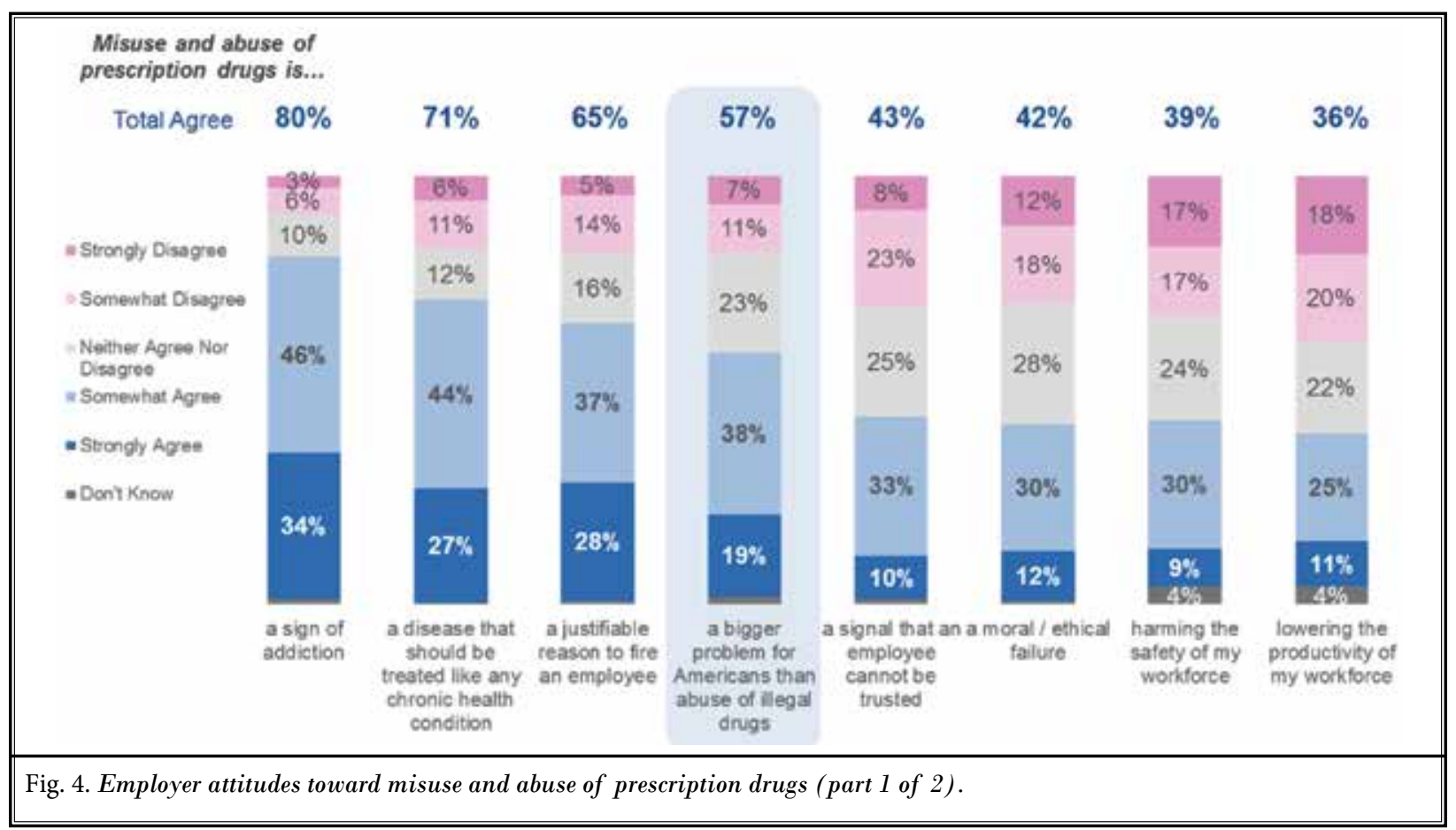

more likely to ensure careful monitoring of the employee (Table 3).

\section{Impact of prescription drug use on the workplace}

Respondents were asked to report if, to their knowledge, their firms had experienced any of several impacts of prescription drug use on their workforce (Fig. 6).

Thirty-nine percent of employers have experienced employees taking prescription pain relievers at work, a number identical to those who have noticed absentee- 


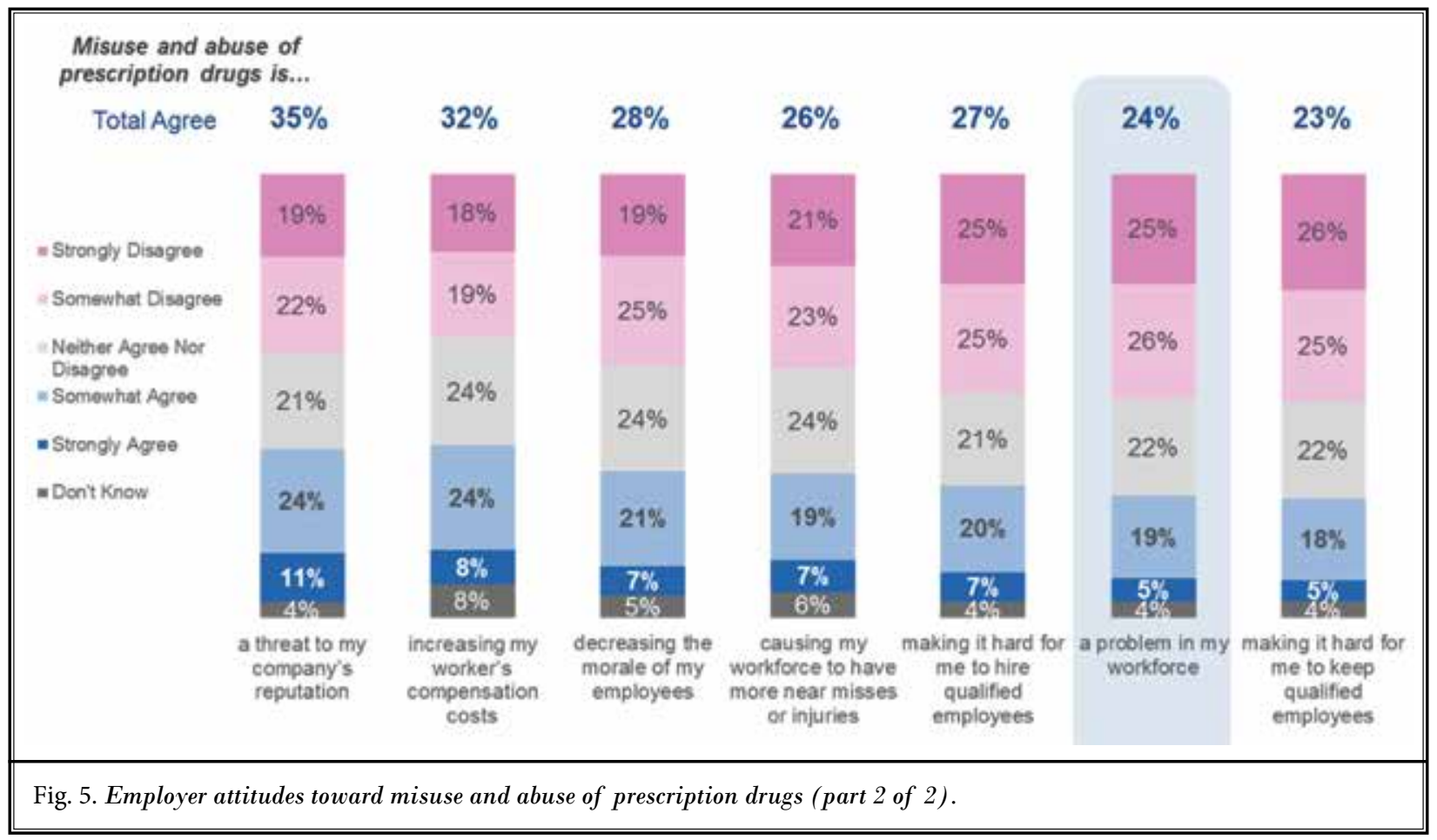

Table 3. Employer attitutdes toward misuse and abuse of prescription drugs by likely approach to employee abuse of prescription drugs.

\begin{tabular}{|c|c|c|c|c|}
\hline \multirow{2}{*}{$\begin{array}{l}\text { Misuse and abuse of } \\
\text { prescription drugs is... }\end{array}$} & \multirow[b]{2}{*}{$\begin{array}{c}\text { Total } \\
\text { Agreement }\end{array}$} & \multicolumn{3}{|c|}{ By tikely Approach To Emploves Abuse of Prescription Drupg: } \\
\hline & & $\begin{array}{l}\text { Roturn to Position afler } \\
\text { Treament }\end{array}$ & $\begin{array}{l}\text { Ensure Careful } \\
\text { Moniloring }\end{array}$ & Dismiss Then \\
\hline Base & 501 & 242 & 109 & 102 \\
\hline a sign of addiction & $80 \%$ & $79 \%$ & $85 \%$ & $83 \%$ \\
\hline a disease to be treated like any chronic condition & $71 \%$ & $75 \%$ & $68 \%$ & $66 \%$ \\
\hline a justifiable reason to fire an employee & $65 \%$ & $55 \%$ & $68 \%$ & $92 \%$ \\
\hline a bigger problem for than abuse of illegal drugs & $57 \%$ & $59 \%$ & $56 \%$ & $53 \%$ \\
\hline a signal that an employee cannot be trusted & $43 \%$ & $35 \%$ & $50 \%$ & $59 \%$ \\
\hline a moral / ethical failure & $41 \%$ & $36 \%$ & $51 \%$ & $47 \%$ \\
\hline harming the safety of my workforce & $39 \%$ & $35 \%$ & $44 \%$ & $43 \%$ \\
\hline lowering the productivity of my workforce & $36 \%$ & $31 \%$ & $45 \%$ & $37 \%$ \\
\hline a threat to my company's reputation & $35 \%$ & $25 \%$ & $46 \%$ & $44 \%$ \\
\hline increasing my worker's compensation costs & $31 \%$ & $29 \%$ & $37 \%$ & $34 \%$ \\
\hline decreasing the morale of my employees & $28 \%$ & $25 \%$ & $38 \%$ & $26 \%$ \\
\hline causing my workforce to have near misses/injuries & $27 \%$ & $21 \%$ & $32 \%$ & $32 \%$ \\
\hline making it hard for me to hire qualified employees & $26 \%$ & $21 \%$ & $33 \%$ & $30 \%$ \\
\hline a problem in my workforce & $24 \%$ & $19 \%$ & $36 \%$ & $22 \%$ \\
\hline making it hard for me to keep qualified employees & $23 \%$ & $18 \%$ & $34 \%$ & $24 \%$ \\
\hline
\end{tabular}

ism for the same reason. Meanwhile, $29 \%$ of employers have noticed decreased performance or seen family members affected by the effects of prescription drugs. Also of particular concern, one in 10 employers have witnessed an arrest or overdose due to prescription drugs. In total, $71 \%$ of employers have been affected in some way by employee use of prescription drugs, $47 \%$ have experienced absenteeism or impaired worker 


\section{Incidents Experienced Due To Prescription Drug Usage ...}

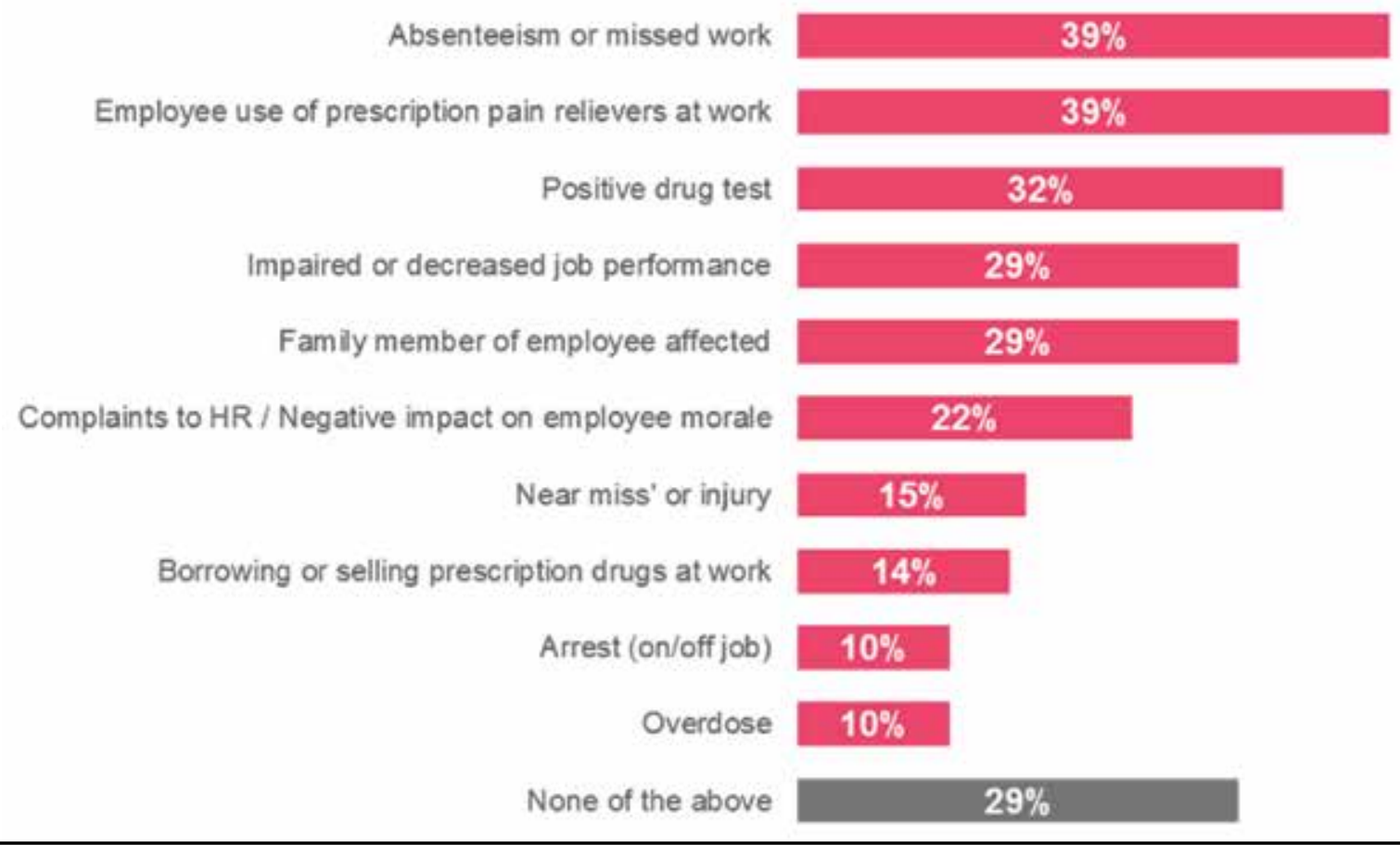

Fig. 6. Prevalence of workplace incidents attributed to prescription drug usage.

performance, and $26 \%$ have experienced a near-miss/ injury, overdose, or arrest.

Further stratification reveals that organizations that lack an employee assistance program, employee drug testing, and formal training on prescription drug usage are significantly more likely to not have experienced any of these incidents (Table 4). This suggests that either they are unaware of the issue, or perhaps that these policies are created and implemented as reactionary measures.

Employers whose organization lacks the expertise to deal with prescription drug abuse are significantly more likely to feel the negative business impact (e.g., absenteeism and impaired performance), as well as to experience near-miss or injury events (Table 5).

As expected, the smallest firms are significantly less likely to have experienced an incident, with only $50 \%$ reporting any of the issues queried (Table 6). Mid-to-large-sized firms (500 to 1,000 employees) are significantly more likely to have experienced an incident - particularly absenteeism and complaints to HR or impact on employee morale.

\section{Identifying and responding to drug abuse}

On a 4-point Likert scale from "not at all confident" to "very confident," respondents were asked to describe their organization's ability to identify behaviors consistent with misuse/abuse of prescription drugs (Fig. 7). Around 4 in 10 employers are not confident that individual employees can spot warning signs of prescription drug abuse. Similarly, around one in 4 is not confident that managers or supervisors can spot signs, either. Even at the HR department level, HR decision-makers claim that only around one-fifth of HR departments can spot warning signs of prescription drug issues. These findings suggest a need for more education and training related to misuse/abuse of prescription drugs. Not surprisingly, employers who offer formal workplace training about prescription drugs feel significantly more confident in the ability of HR decision-makers, HR departments, and supervisors/managers to spot these warning signs, but this additional confidence does not extend to the individual employee level. 


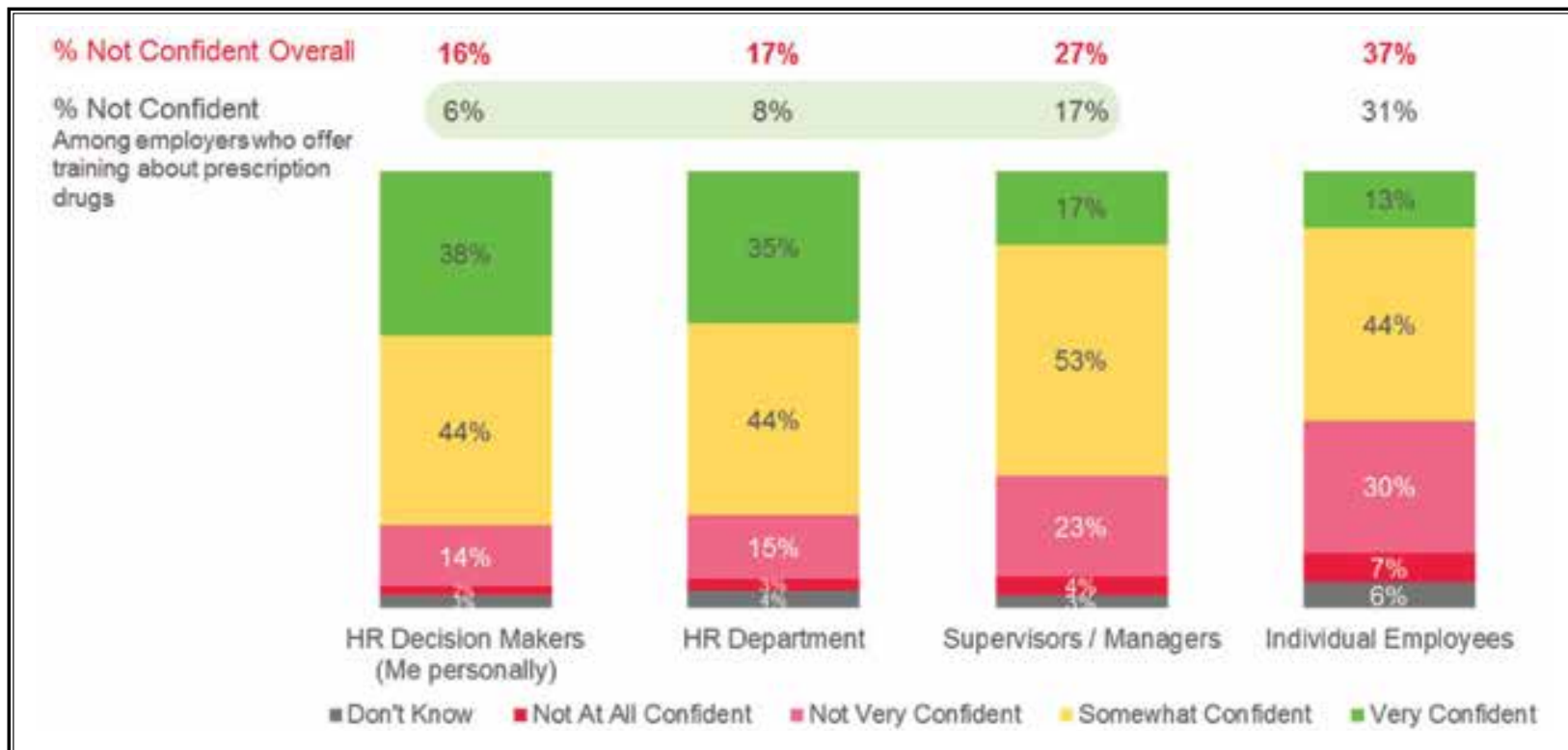

Fig. 7. Employer confidence in ability to recognize behaviors consistent with misuse or abuse of prescription drugs.

\section{Ability to handle prescription drug abuse in the workplace}

On a 4-point Likert scale from "not at all confident" to "very confident," employers rated their ability to handle various aspects of prescription drug misuse/ abuse among their employees. Under half of US employers are very confident that they have policies in place for dealing with prescription drug issues (Fig. 8). Those who lack this confidence are significantly more likely to say that the issue is not a priority for their institution. Those organizations that lack formal policies and processes are significantly more likely to say that their organization is poorly prepared to deal with the issue overall. Employers with unionized employees are significantly more confident in recovery processes after treatment than their nonunionized counterparts.

Confidence is generally higher among those whose organizations have formal employee assistance programs, drug testing programs, or employee training on prescription drug usage (Table 7). Moreover, organizations that offer training are significantly more likely to agree that they have appropriate policies in place to deal with this issue.

NSC members are significantly more likely to feel confident that management and supervisors have effective procedures to follow once signs of misuse/abuse have been identified.

\section{Common responses to substance abuse}

Organizations were asked to characterize their organization's approach to misuse or abuse of various substances. The most common response to prescription drug and alcohol abuse is to return people to work after treatment (Table 8). It is also the most common response for marijuana abuse, although a higher proportion of employers would dismiss employees for marijuana use than for prescription drugs and alcohol. For abuse of other illegal substances, the most common response is dismissal rather than treatment or help.

\section{Policy coverage and workplace initiatives}

Employers were surveyed on various topics related to prescription drug use in their formal written policies (Fig. 9). Drug testing is the topic most likely to be covered by employer policies, followed by employee use of illicit drugs and return-to-work policies for employees undergoing substance abuse treatment. Significantly fewer employers have policies covering medical marijuana and processes for notifying superiors of prescription drug misuse/abuse. Two-thirds of US employers specifically cover use of prescription drugs at work in their policies. However, for most issues, more than one in 10 HR decision-makers don't know whether a topic is covered by their policies. Only $19 \%$ cover all the issues listed. 


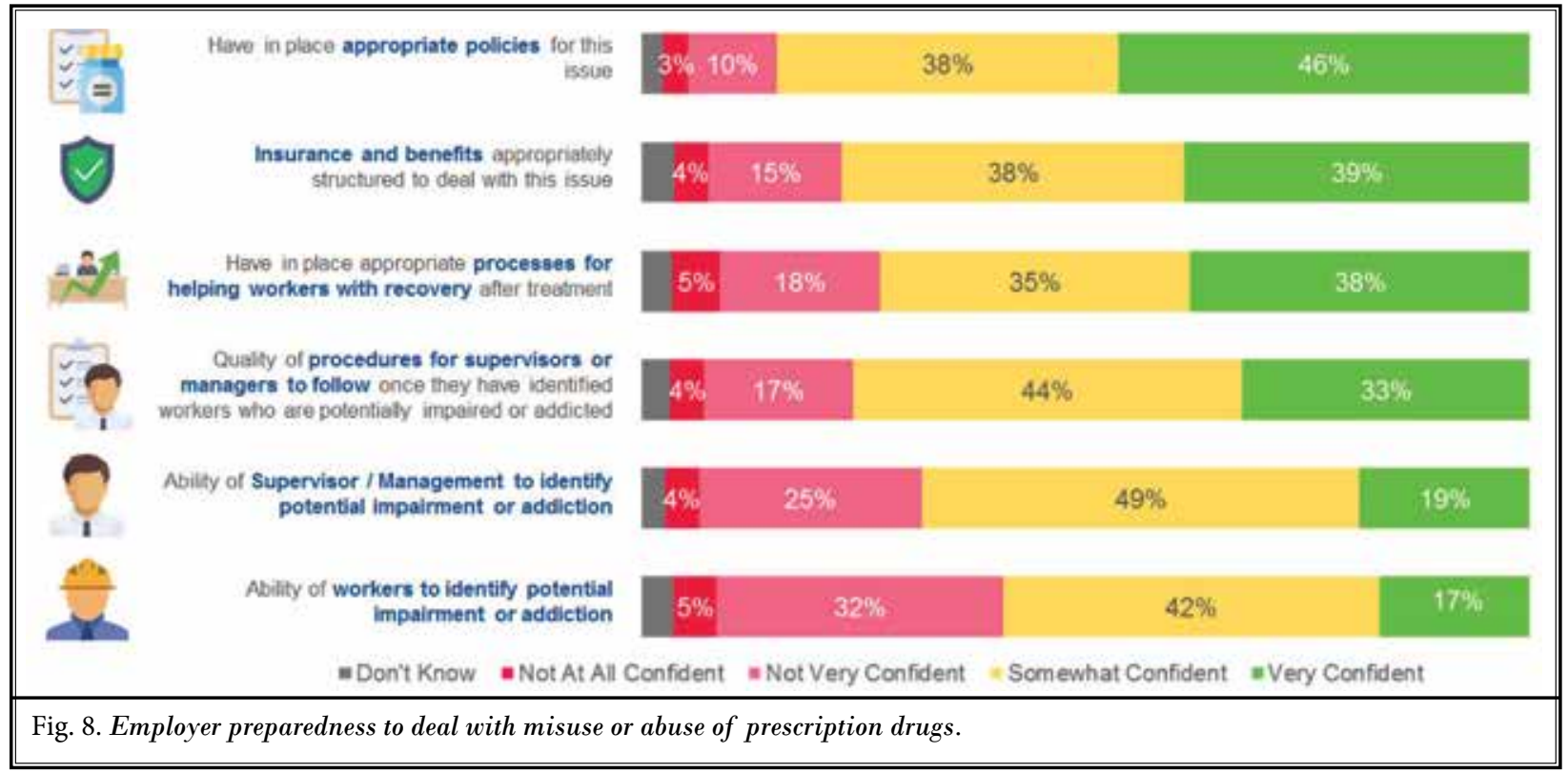

Table 7. Employer preparedness to deal with misuse and abuse of prescription drugs by available policies and programs.

\begin{tabular}{|c|c|c|c|c|c|}
\hline & \multirow[b]{2}{*}{ Overall } & \multicolumn{4}{|c|}{ ByPoliciesfrogramsubedin Oroanization } \\
\hline & & $\begin{array}{l}\text { Hes Employee } \\
\text { Assistance } \\
\text { Program (EAP) }\end{array}$ & $\begin{array}{l}\text { Pertorms Drug } \\
\text { Testing On } \\
\text { Employees }\end{array}$ & $\begin{array}{l}\text { Orfers Training On } \\
\text { PD Usage A } \\
\text { Workplace }\end{array}$ & None of These \\
\hline Bese & 501 & 400 & 286 & 118 & 34 \\
\hline Heve in place appropriate policies for this issue & $46 \%$ & $47 \%$ & $52 \%$ & $64 \%$ & $38 \%$ \\
\hline $\begin{array}{l}\text { Insurance and benefits appeopriately structured to deal with this } \\
\text { issue }\end{array}$ & $39 \%$ & $42 \%$ & $41 \%$ & $47 \%$ & $21 \%$ \\
\hline $\begin{array}{l}\text { Hawe in place appropriate processes for helping workers with } \\
\text { recovery affer treatrnent }\end{array}$ & $38 \%$ & $41 \%$ & $42 \%$ & $60 \%$ & $18 \%$ \\
\hline $\begin{array}{l}\text { Quality of procedures for supervisors or manapers to follow } \\
\text { once they have identified workers who are potentialy mpaired or } \\
\text { addicted }\end{array}$ & $33 \%$ & $34 \%$ & $37 \%$ & $51 \%$ & $12 \%$ \\
\hline $\begin{array}{l}\text { Ability of Supervisor / Management to identify potential } \\
\text { impairment or addiction }\end{array}$ & $19 \%$ & $17 \%$ & $22 \%$ & $30 \%$ & $6 \%$ \\
\hline Ability of workers to identify potential impairment or addiction & $17 \%$ & $15 \%$ & $19 \%$ & $22 \%$ & $12 \%$ \\
\hline
\end{tabular}

Drug testing and employee responsibility for notifying supervisors of prescription drug use are most evident in the industrial field (Table 9). Return-towork policies, interactive processes, and performance improvement plans are covered more often in larger organizations with more than 1,000 employees than in their smaller counterparts.

\section{Workplace addiction initiatives}

Employers were specifically asked about the pres- ence of employee assistance programs, employee drug testing, and workplace prescription drug training programs. Four in 5 employers have an employee assistance program, and these organizations are significantly more likely to return employees abusing all substances surveyed to work after instances of abuse. By contrast, organizations that perform drug testing on employees are significantly more likely to dismiss employees found to be abusing any of the substances surveyed. Organizations with none of the 3 programs 
Table 8. Employer response to substance misuse and abuse.

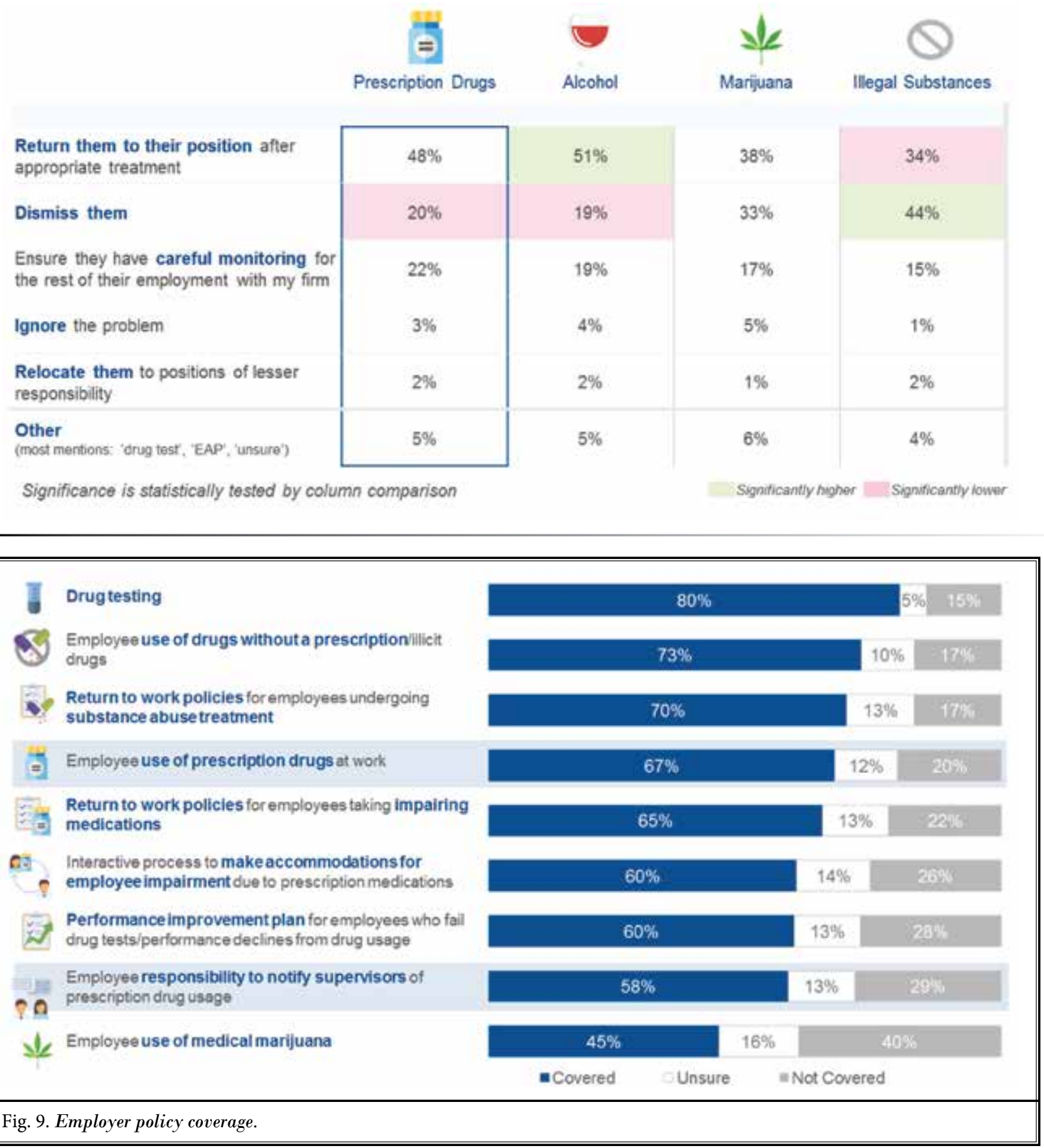

queried are significantly less likely to return marijuana misusers to work after treatment, though these organizations have a low base (only $7 \%$ of the sample) and therefore do not show any other statistically significant differences.

\section{8(A) Employee assistance programs}

Eighty percent of firms surveyed have an employee assistance program. Organizations with an employee assistance program are significantly more likely to return employees to work after treatment for all sub- 
Table 9. Employer policy coverage by industry type and organization size.

\begin{tabular}{|c|c|c|c|c|c|c|c|}
\hline & \multirow[b]{2}{*}{ \% Concern } & \multicolumn{4}{|c|}{ Industry Type: } & \multicolumn{2}{|c|}{ Organkation Slae } \\
\hline & & Industrial & $\begin{array}{l}\text { Public \& } \\
\text { Social } \\
\text { Services }\end{array}$ & $\begin{array}{l}\text { Professional } \\
\text { Services }\end{array}$ & $\begin{array}{c}\text { Retail } 8 \\
\text { Wholesale }\end{array}$ & $\begin{array}{l}1,000 \\
\text { employees or } \\
\text { less }\end{array}$ & $\begin{array}{l}\text { Over } 1,000 \\
\text { employees }\end{array}$ \\
\hline Base & $50 t$ & 148 & 138 & 120 & 47 & 309 & 192 \\
\hline Drug testing & $80 \%$ & $91 \%$ & $76 \%$ & $76 \%$ & $81 \%$ & $78 \%$ & $84 \%$ \\
\hline $\begin{array}{l}\text { Engioyee use of drugs wiflout a preacription/licit } \\
\text { drugs }\end{array}$ & $73 \%$ & $76 \%$ & $72 \%$ & $68 \%$ & $72 \%$ & $71 \%$ & $76 \%$ \\
\hline $\begin{array}{l}\text { Return to work policies for employees undergoing } \\
\text { substance abuse trvehnent }\end{array}$ & $70 \%$ & $78 \%$ & $75 \%$ & $59 \%$ & $64 \%$ & $66 \%$ & $76 \%$ \\
\hline Employee use of prescription drugs at work & $67 \%$ & $74 \%$ & $66 \%$ & $63 \%$ & $66 \%$ & $66 \%$ & $70 \%$ \\
\hline $\begin{array}{l}\text { Return to work policies for employees taking } \\
\text { impairing medications }\end{array}$ & $65 \%$ & $73 \%$ & $70 \%$ & $56 \%$ & $55 \%$ & $59 \%$ & $74 \%$ \\
\hline $\begin{array}{l}\text { Interactwo process to make accoenmodations for } \\
\text { impairment }\end{array}$ & $60 \%$ & $53 \%$ & $62 \%$ & $63 \%$ & $60 \%$ & $56 \%$ & $67 \%$ \\
\hline $\begin{array}{l}\text { Performance improvement plan for ecoplioyees who } \\
\text { have falled drug tests }\end{array}$ & $60 \%$ & $66 \%$ & $62 \%$ & $53 \%$ & $57 \%$ & $52 \%$ & $72 \%$ \\
\hline $\begin{array}{l}\text { Emoloyee responsibity to notity supervisors of } \\
\text { preseription druo usage }\end{array}$ & $58 \%$ & $69 \%$ & $52 \%$ & $53 \%$ & $53 \%$ & $56 \%$ & $62 \%$ \\
\hline Employee use of medical marfeuana & $45 \%$ & $51 \%$ & $38 \%$ & $41 \%$ & $60 \%$ & $44 \%$ & $46 \%$ \\
\hline
\end{tabular}

stances surveyed. Around 9 in 10 employers (89\%) use their employee assistance program to offer anonymous guidance and support to employees. Half (51\%) use it to develop a plan for assessment and treatment of issues. Those who offer workplace training about prescription drugs are significantly more likely to use their employee assistance program to develop a plan and identify issues.

\section{8(B) Employee drug testing}

Fifty-seven percent of respondents perform drug testing. Drug testing organizations are significantly less likely to "ignore the problem" for all substances surveyed than those without drug testing. They are also significantly more likely to dismiss employees after discovering abuse for all substances surveyed than those without drug testing. Over 4 in 5 employers (83\%) who conduct drug tests subject any employee to testing. Those working in public administration or those required by government regulation are significantly more likely to specifically test employees in risky roles such as those operating machinery, tools, or vehicles. American Traffic Safety Services Association (ATSSA) members are more likely to drug test client-facing employees. Three in 4 organizations $(74 \%)$ conduct drug testing at their own discretion. Only $41 \%$ of employers are compelled by industry and government regulation, suggesting business benefits and employee needs are key drivers.
Around 9 in $10(88 \%)$ drug-testing employers conduct drug tests pre-hire; the most common timing otherwise is post accident $(62 \%)$ or when the need arises based on incidents with reasonable suspicion (65\%). Fortyfive percent of drug-testing employers test for all the substances in the 5-panel drug test (Fig. 10). Cannabinoids, cocaine, opiates, and amphetamines are other commonly tested substances. There are no differences in who is tested, why, or how often, suggesting that the substance tested for does not affect the testing process itself.

\section{8(C) Workplace prescription drug training}

Twenty-four percent of employers offer workplace training on prescription drug misuse/abuse. This attribute is the highest driver of overall preparedness to deal with the issue of prescription drug misuse/ abuse. Sixty-eight percent of employers who offer prescription drug training offer it to all employees, a strategy that is $27 \%$ more common with single-site employers than with multisite employers. Seventeen percent of all US employers therefore offer all employees training on the topic. The only statistically significant difference is that organizations with at least some employees under union contracts are significantly more likely to train only HR employees or supervisors/managers, and significantly less likely to train the entire workforce. 


\begin{tabular}{|c|c|c|}
\hline \multirow{13}{*}{$\begin{array}{l}5 \text { Panel } \\
\text { Drug Test }\end{array}$} & & $\%$ TestedFor \\
\hline & Cannabinoids (Marijuana, THC) & $78 \%$ \\
\hline & Cocaine & $77 \%$ \\
\hline & Opiates (Codeine, Morphine, Heroin) & $76 \%$ \\
\hline & Amphetamines (including Methamphetamine) (Adderall, Ritalin, etc.) & $67 \%$ \\
\hline & Barbiturates (Seconal, phenobarbital, etc.) & $59 \%$ \\
\hline & Synthetic Opioids (Oxycodone, Hydrocodone, Dilaudid, Fentanyl, etc.) & $59 \%$ \\
\hline & Phencyclidine (PCP) & $57 \%$ \\
\hline & Methaqualone (Quaaludes) & $47 \%$ \\
\hline & Benzodiazepines (Xanax, Ativan, Klonopin, Valium, etc.) & $47 \%$ \\
\hline & Methadone & $44 \%$ \\
\hline & Propoxyphene & $31 \%$ \\
\hline & Not Sure & $16 \%$ \\
\hline
\end{tabular}

\section{Insurance coverage of alternative treatment}

On a 4-point Likert scale from "not at all interested" to "extremely interested," employers were asked to report interest in insurance plan coverage for nonpharmacologic treatment modalities (Fig. 11). Of the alternatives, physical therapy is the most commonly covered form of treatment offered by US employers. It is also highly attractive, with 9 out of 10 employers mentioning that they either are interested in covering or already cover physical therapy. Among those who do not currently offer it, $84 \%$ express interest in doing so - the highest of all options surveyed.

Eighty-eight percent are interested in their insurer covering pain relief modalities alternative to prescription drugs. However, $30 \%$ of these employers are not likely to request it of their insurer. Those who are interested and would request that their insurer cover alternative therapies are also significantly more likely to expect the insurer to be responsive to this request (73\%) compared to those who would not request that their insurer augment their coverage $(40 \%)$. Nine percent did not know about their insurer's likely responsiveness.

Geographic differences included less coverage for physical therapy in the South, and increased coverage for acupuncture and massage among Western employers (Table 10). Midwestern employers are significantly less likely to be interested in alternatives than Northeastern employers.

\section{Overall preparedness to deal with the issue}

On a 4-point Likert scale from "extremely well prepared" to "extremely unprepared," employers were asked to gauge their organization's preparedness for handling misuse/abuse of prescription medications among their employees (Fig. 12). Only one in 5 employers feel extremely well prepared to deal with misuse/abuse, while more than one in 4 feels unprepared. Well-prepared organizations tend to be larger, have employees handling risky equipment, and have employees under union contracts or regulations. Employers who have experienced a positive drug test are significantly more prepared ( $83 \%$ ) than those who have not $(67 \%)$.

The presence of a set plan or policies has the largest marginal effect on employers' preparedness to deal with prescription drug misuse/abuse (Fig. 13). Components that hinder employer preparedness include lack of experience, knowledge or training on the issue, as well as the inability to recognize or identify employee misuse/abuse. 


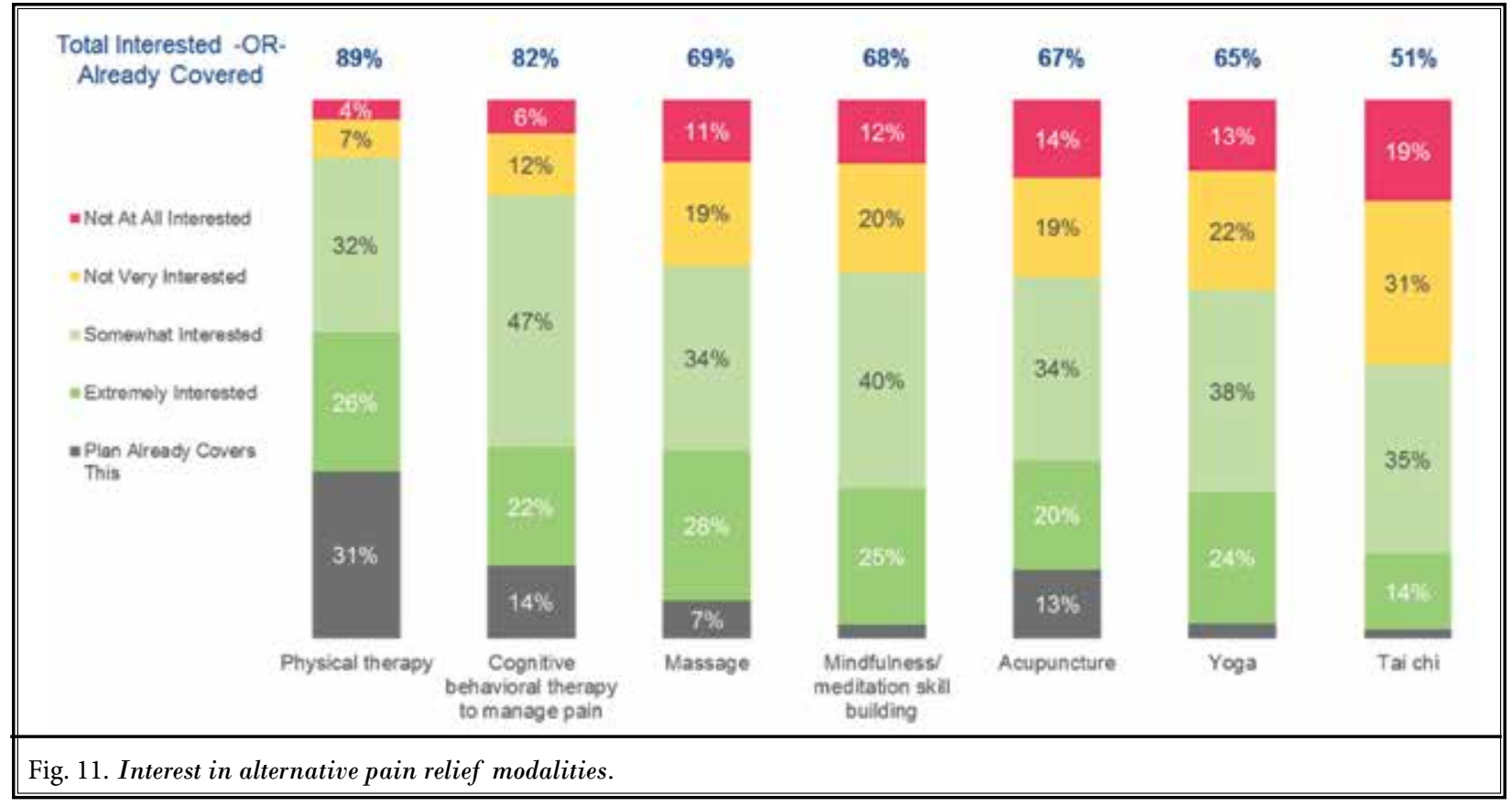

Table 10. Interest in alternative pain relief modalities by region.

\begin{tabular}{|c|c|c|c|c|c|}
\hline & \multirow{2}{*}{ \% Covered } & \multicolumn{4}{|c|}{ Region. } \\
\hline & & Northeast & South & Midwest & West \\
\hline Base & 501 & 103 & 153 & 134 & 111 \\
\hline Physical therapy & $31 \%$ & $38 \%$ & $21 \%$ & $30 \%$ & $40 \%$ \\
\hline Cognitive behavioral therapy to manage pain & $14 \%$ & $17 \%$ & $9 \%$ & $10 \%$ & $20 \%$ \\
\hline Acupuncture & $13 \%$ & $11 \%$ & $8 \%$ & $11 \%$ & $23 \%$ \\
\hline Massage & $7 \%$ & $3 \%$ & $5 \%$ & $5 \%$ & $16 \%$ \\
\hline Yoga & $3 \%$ & $3 \%$ & $3 \%$ & $1 \%$ & $5 \%$ \\
\hline Mindfulness / meditation skill building & $3 \%$ & $4 \%$ & $1 \%$ & $1 \%$ & $5 \%$ \\
\hline Tai chi & $2 \%$ & $4 \%$ & $1 \%$ & $1 \%$ & $2 \%$ \\
\hline
\end{tabular}

While all initiatives improve overall preparedness to deal with the issue, some are bigger drivers than others. The greatest marginal benefit to overall preparedness comes from offering workplace training about prescription drug usage (Fig. 14). This is also the least common initiative among employers. Policies regarding employee use of marijuana is the second strongest driver but is implemented by less than $66 \%$ of employers.

\section{Discussion}

The results suggest that prescription drugs impact the majority of employers, a finding congruent with what is already known about the ubiquity of prescrip- 


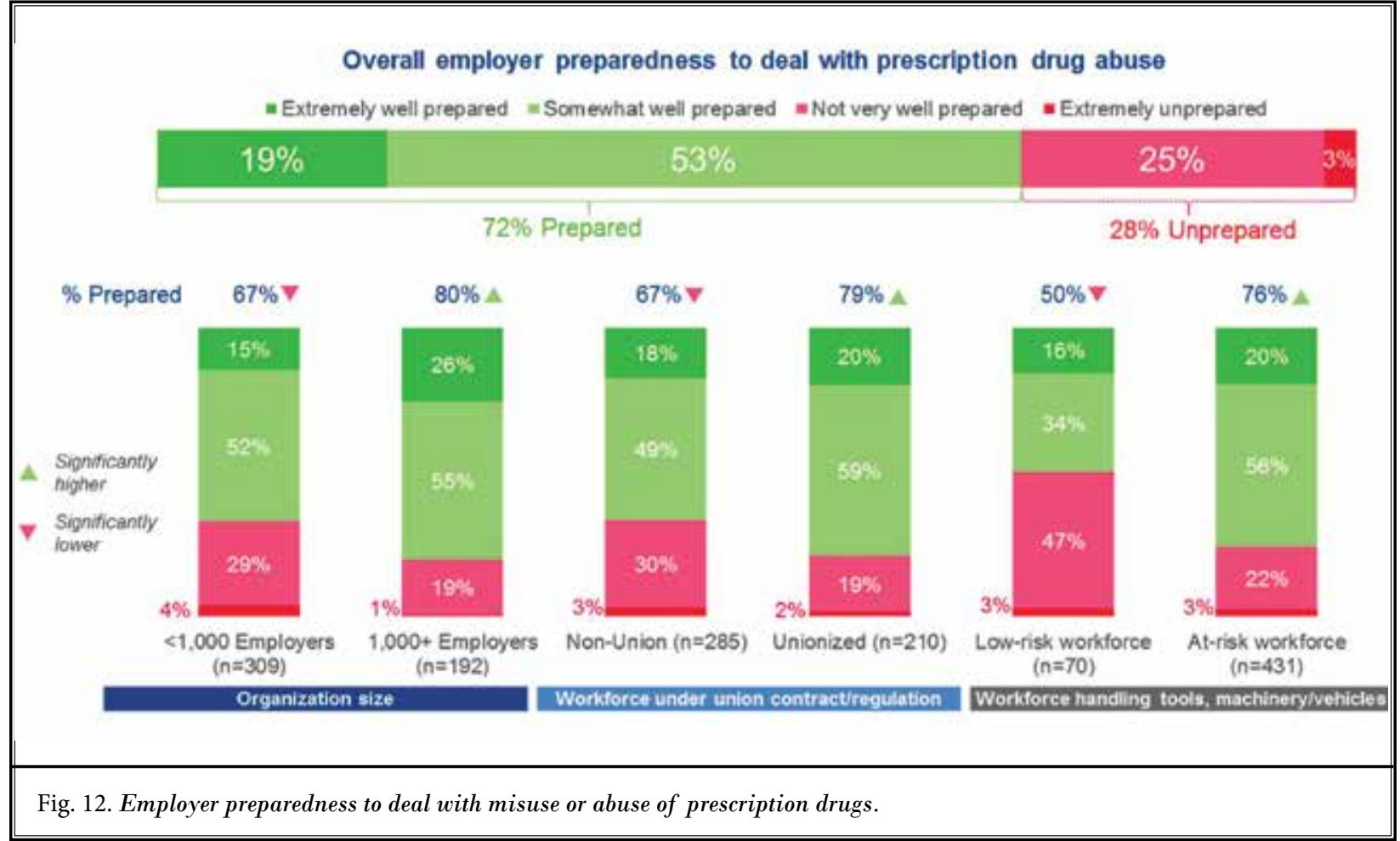

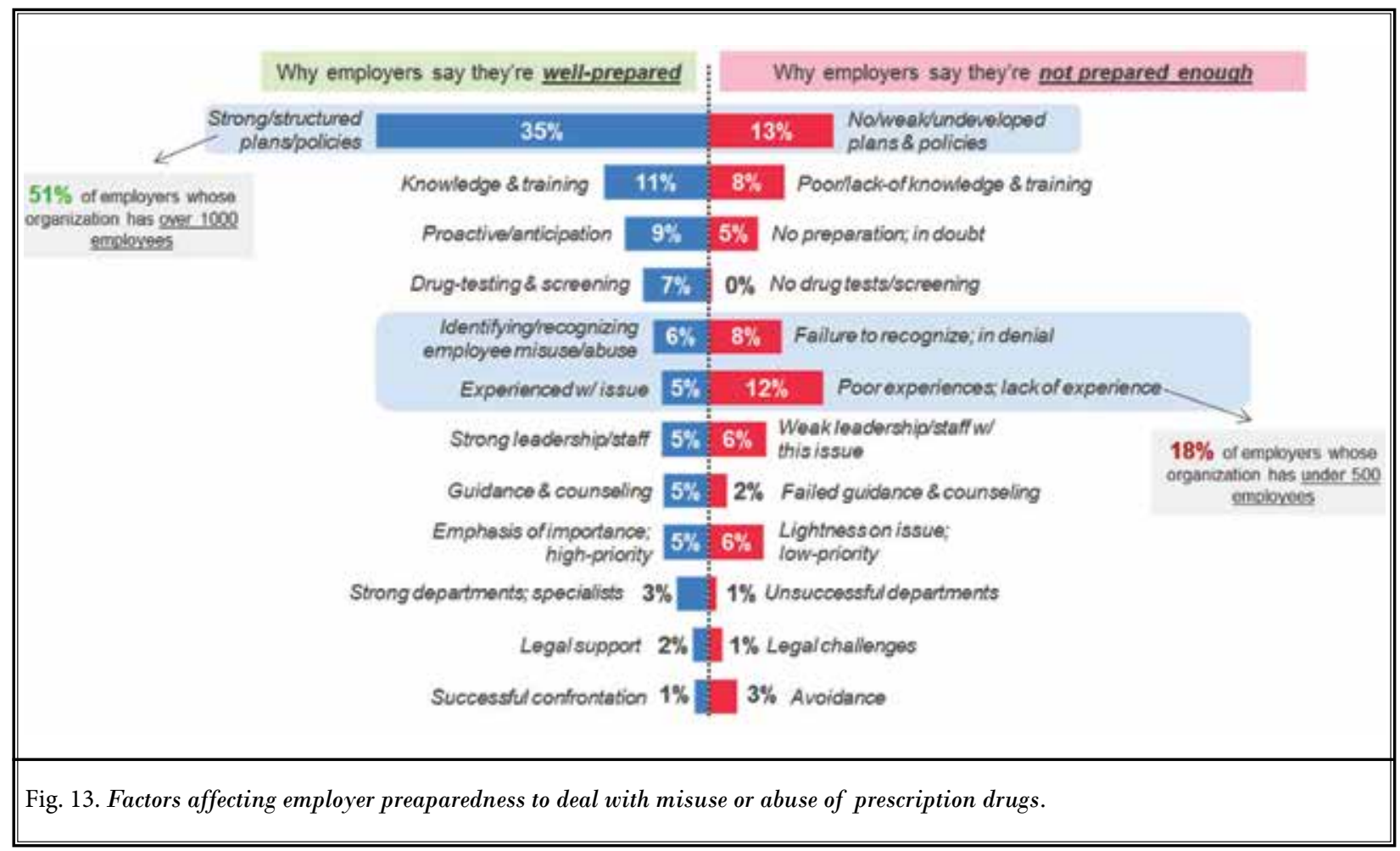




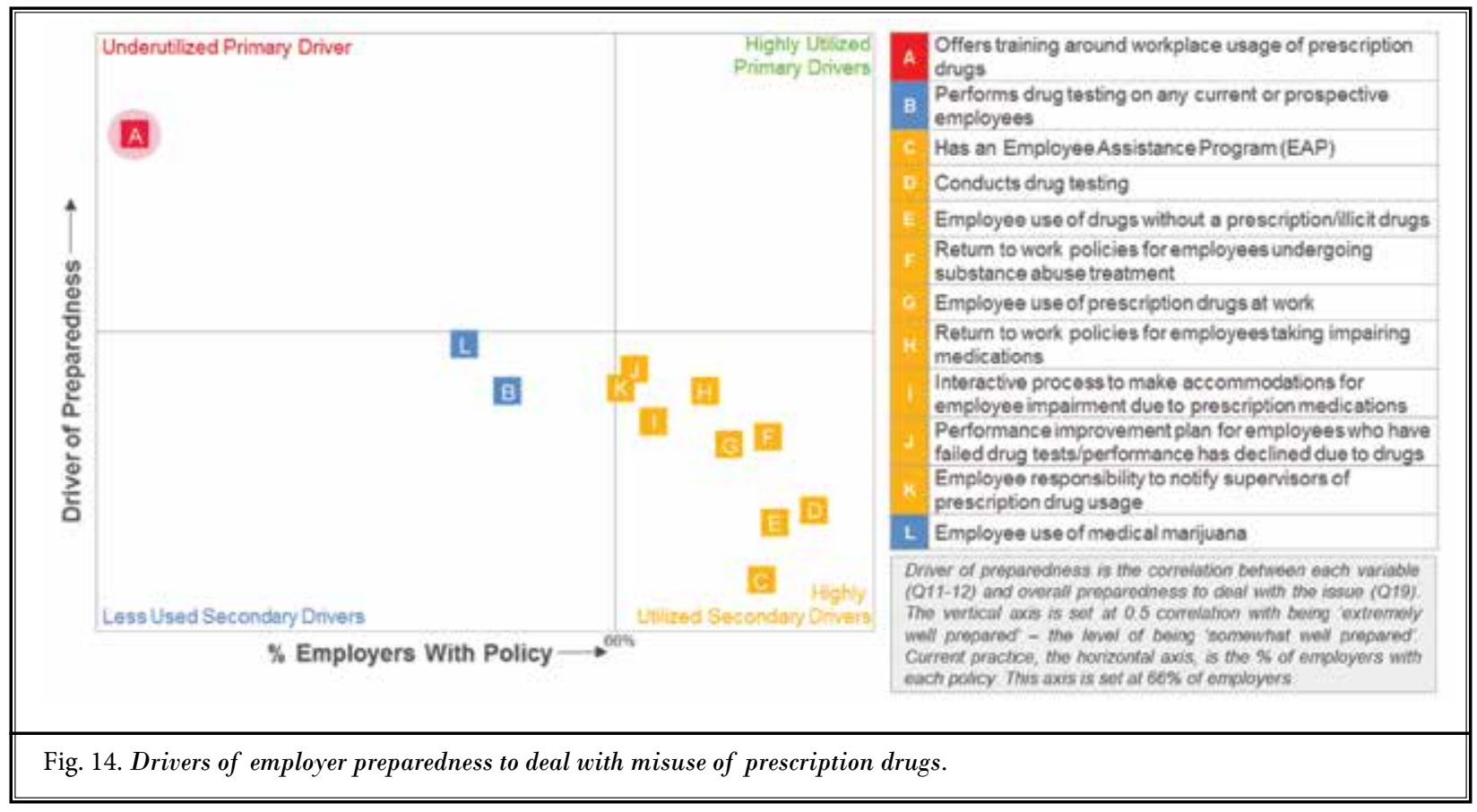

tion analgesics in the United States (Centers for Disease Control and Prevention, 2014) (2). Including negative impacts on employee morale, absenteeism, injuries or near-misses, overdose, illegal sale of prescription drugs, and drug-related arrests, $71 \%$ of surveyed employers have felt the impact of prescription drug use. And, while employers appear to understand the health risks of prescription drug misuse/abuse very well, the associated business impacts are not as well accepted: while the vast majority of employers recognize that prescription drug abuse is related to addiction $(80 \%)$ and is a disease that requires medical treatment $(71 \%)$, significantly fewer employers view prescription drug misuse/ abuse as something that lowers workforce productivity $(36 \%)$, increases total cost of employees $(31 \%)$, or decreases employee morale (28\%). This may partly explain why only $24 \%$ of employers view prescription drugs as a problem in their own workforce despite the near-unanimous concern over employee benefits costs $(95 \%)$. This is somewhat surprising given the well-described economic impact of chronic pain (1) and opioid use (6) in the United States, as well as the negative externalities that troubled employees exert on their coworkers (8).

A significant number of employers do not feel prepared to deal with issues surrounding prescription drug abuse. Twenty-eight percent of employers report being either "not very well prepared" or "extremely unprepared" to deal with these issues. Specifically, organizations that are smaller, lack union contracts or regulatory oversight, and lack employees who operate tools, vehicles, or heavy machinery are significantly more likely to report unpreparedness. This is a consistent national pattern with no noteworthy differences by region or industry. However, the results make clear that formal policies and processes significantly improve preparedness. Employers who engage any of the initiatives surveyed (employee assistance program, employee drug testing, or workplace prescription drug training) are significantly more likely to consider their organization prepared to deal with prescription drug abuse than their counterparts. For example, $95 \%$ of those who offer relevant workplace training about prescription drug use and misuse feel prepared to deal with the issue. Specifically, workplace prescription drug training appears to be the strongest driver of employer preparedness. It is also the least frequently implemented initiative, exercised by only $24 \%$ of employers, which suggests a significant degree of underutilization. While the characteristics of an effective workplace prescription drug training program are not specifically investigated, resources for workforce training are widely available from organizations such as the Substance Abuse and Mental Health Services Administration (9). Moreover, employee prescription drug training meshes 
well with the proposed nationwide educational campaign to promote safer use of prescription analgesic medications that is outlined in the National Institutes of Health (NIH) National Pain Strategy (10), suggesting a national climate that may be receptive to more widespread adoption of training programs.

The survey also reveals significant interest in alternatives to prescription drugs. Specifically, $88 \%$ of employers are interested in their insurer offering alternative options for pain management. Physical therapy is the most commonly covered treatment of the surveyed alternatives as well as the most attractive option for those who do not offer it. Cognitive behavioral therapy follows as the next most commonly covered and most attractive option. These interests also fit perfectly within the current national landscape, as the Centers for Disease Control and Prevention have published guidelines outlining the appropriate prescribing practices of opioid analgesics (11) and the NIH's National Pain Strategy places emphasis on integrative and interdisciplinary health care for management of chronic pain (10).

\section{Conclusion}

Prescription drug use represents a significant concern for American employers, especially the use of opioid analgesics. Seven in 10 employers report being affected on some level by their use. While the health effects of prescription drug misuse/abuse are clear, employers are less likely to recognize their negative business impacts. Employers also report significant unpreparedness for dealing with employee misuse and abuse of prescription drugs. However, firms that employ formal policies and programs - especially workplace prescription drug training programs - are more likely to feel prepared to deal with issues of misuse and abuse. Interest in nonpharmacologic treatment modalities is high, especially physical and cognitive based therapy. These findings dovetail with a national climate that places increasing scrutiny on prescription analgesics and represent a potential opportunity to effect significant change in the management of chronic pain conditions in this country.

\section{Limitations}

This is a survey study with descriptive analysis of survey data. There was limited sample size.

\section{REFERENCES}

1. Institute of Medicine. Relieving pain in America: A blueprint for transforming prevention, care, education, and research. Washington, DC. The National Academies Press. 2011.

2. Centers for Disease Control and Prevention. Opioid painkiller prescribing, where you live makes a difference. Atlanta, GA. Centers for Disease Control and Prevention. 2014. www.cdc.gov/vitalsigns/ opioid-prescribing

3. Daubresse M, Chang HY, Yu Y, Viswanathan S, Shah ND, Stafford RS, Kruszewski SP, Alexander GC. Ambulatory diagnosis and treatment of non-malignant pain in the United States, 20002010. Medical Care 2013; 51:10.

4. Center for Behavioral Health Statistics and Quality. Key substance use and mental health indicators in the United
States: Results from the 2015 National Survey on Drug Use and Health. HHS Publication No. SMA 16-4984, NSDUH Series H-51, 2016.

5. Kirson NY, Scarpati LM, Enloe CJ, Dincer AP, Birnbaum HG, Mayne TJ. The economic burden of opioid abuse: updated findings." Journal of Managed Care \& Specialty Pharmacy 23, 2017; 4:427-445.

6. Florence C. S., Zhou C., Luo F., Xu L. The economic burden of prescription opioid overdose, abuse, and dependence in the United States. 2013. Medical Care 54, 901-906.

7. National Safety Council. National Employer Survey: Prescription drugs and the US workforce. January, 2017: www.nsc. org/Portals/o/Documents/NewsDocuments/2017/National-Employer-Addiction-Survey-Methodology.pdf
8. Lehman WEK, Farabee D, Bennett JB. Perceptions and correlates of co-worker substance use. Employee Assistance Quarterly 1998; 13:1-22.

9. Substance Abuse and Mental Health Services Administration (SAMHSA). Drug-free Workplace Programs. www. samhsa.gov/workplace. Updated 6/8/2017. Accessed 10/7/2017.

10. National Institute of Health $(\mathrm{NIH})$. National Pain Strategy: A comprehensive population health-level strategy for pain. 2017. https://iprcc.nih.gov/ sites/default/files/HHSNational_Pain_ Strategy_508C.pdf. Accessed October 7, 2017.

11. Centers for Disease Control and Prevention. CDC Guidelines for Prescribing Opioids for Chronic Pain. Recommendations and Reports. March 18, 2016; 65:1-49. 